\title{
Numerical Taxonomy and Deoxyribonucleic Acid Relatedness of Environmental and Clinical Vibrio Species Isolated in Indonesia
}

\author{
E. MOLITORIS,${ }^{1,2}$ M. A. MARII,${ }^{1,3}$ S. W. JOSEPH, ${ }^{1 *}$ M. I. KRICHEVSKY, ${ }^{2}$ G. R. FANNING, ${ }^{4}$ G. LAST, ${ }^{1}$ \\ A. M. EL-MISHAD, ${ }^{3}$ Y. A. EL BATAWI, ${ }^{3}$ AND R. R. COLWELL ${ }^{1}$ \\ Department of Microbiology, University of Maryland, College Park, Maryland 20742 ${ }^{1}$; Microbial Systematics Section, \\ National Institute of Dental Research, Bethesda, Maryland $20205^{2}$; Department of Microbiology, \\ Faculty of Medicine, Cairo University, Cairo, Egypt ${ }^{3}$; and Biochemistry Division, \\ Walter Reed Army Institute of Research, Washington, D.C. $20307^{4}$
}

Received 4 January 1989/Accepted 31 July 1989

\begin{abstract}
Numerical taxonomic methods were used to analyze taxonomic data gathered for 229 Vibrio strains isolated from fecal, seawater, and seafood specimens collected in Jakarta, Indonesia. Simple matching and Jaccard coefficients yielded similar results. Most of the clinical isolates were identified as Vibrio parahaemolyticus, $V$. cholerae, or $V$. mimicus. Environmental isolates included $V$. alginolyticus and one strain of $V$. vulnificus. Clusters of $V$. parahaemolyticus included both clinical and environmental isolates. Biotypes of $V$. parahaemolyticus were not associated with a specific source. Reference strains of other Vibrio species did not cluster with any of the isolates examined in this study. Four groups remained initially unidentified and were further subjected to deoxyribonucleic acid hybridization analysis, which enabled their identification as $V$. parahaemolyticus, $V$. alginolyticus, or possible new Vibrio spp. Descriptions of Vibrio species already published proved useful in identifying and classifying most of the isolates from a tropical climate.
\end{abstract}

The taxonomy of the genus Vibrio has undergone significant revision during the past 15 years. There are currently some 20 species, and at least 14 more have been proposed (2). Recently, separation of the genus Vibrio into three genera, Vibrio, Shewanella, and Listonella, has been recommended (20).

At least 11 Vibrio species have been found to be associated with human gastroenteritis, wound infections, or septicemia. Vibrio cholerae and V. parahaemolyticus cause gastroenteritis and have been isolated worldwide (13). $V$. vulnificus, $V$. alginolyticus, and $V$. damsela have been isolated from wounds of patients after exposure to seawater and also have a worldwide distribution $(13,19,26) . V$. fluvialis, $V$. furnissii, $V$. metschnikovii, $V$. mimicus, $V$. cincinnatiensis, and $V$. hollisae have been associated with gastroenteritis or wound infections $(3,6,16,18)$. Generally, these pathogens share estuarine, neritic, or brackish marine environments and can be isolated from a variety of environmental samples. Other species, including $V$. fischeri, $V$. splendidus, $V$. natriegens, $V$. nereis, and $V$. pelagius, inhabit pelagic regions and may occur only transiently in estuarine environments $(1,2)$.

Nonpathogenic Vibrio species, including $V$. aestuarianus, $V$. anguillarum, V. campbelli, V. carchariae, V. costicola, $V$. diazotrophicus, $V$. gazogenes, $V$. harveyi, $V$. logei, $V$. marinus, $V$. mediterranei, $V$. nigripulchritudo, $V$. ordalii, $V$. orientalis, V. proteolyticus, V. psychroerythrus, V. salmonicida, and $V$. tubiashii, are currently recognized as members of the genus (10).

Development of biochemical and physiological methods for classification of members of the family Vibrionaceae has changed rapidly in recent years $(2,20,33)$. Kaper et al. (14) stated that the best approach to the enigma of environmental versus clinical origin of Vibrio species requires integration of systematics and ecology. In this study, both environmental and clinical Vibrio isolates from a tropical country, Indone-

* Corresponding author. sia, were subjected to numerical taxonomy. The strains were initially characterized by methods developed for enteric organisms, except for the use of increased $\mathrm{NaCl}$ concentrations in the media. The description of Vibrio species has recently been expanded by incorporation of nutritional data derived from sole carbon source utilization tests (2). In this study, nutritional screening of 229 strains was done and the characteristics of both temperate and tropical Vibrio spp. were recorded. Selected unidentified strains were further characterized by using deoxyribonucleic acid (DNA) hybridization analysis.

\section{MATERIALS AND METHODS}

Bacterial strains. Presumptive Vibrio strains $(n=229)$ were isolated from seafood, seawater, and human fecal specimens collected in Jakarta, Indonesia (12), and in the original selection, emphasis was placed on the isolation of species other than $V$. cholerae. Isolates were lyophilized for long-term storage.

Upon initiation of the study reported here, lyophilized cultures were revived by suspending the pellets in $1 \%$ tryptone broth (Oxoid Ltd., Basingstoke, England) supplemented with $1 \%$ (wt/vol) $\mathrm{NaCl}\left(\mathrm{T}_{1} \mathrm{~N}_{1}\right)$ and incubated at $25^{\circ} \mathrm{C}$ for $48 \mathrm{~h}$. Each isolate was examined for purity by being subcultured twice onto nutrient agar (NA) (Lab-Lemco agar; Oxoid) supplemented with $1 \% \mathrm{NaCl}$. Working cultures were maintained at ambient temperature on NA slants under mineral oil.

Reference strains, including pathogenic and nonpathogenic Vibrio species, were treated similarly. The following strains were obtained from the American Type Culture Collection (ATCC), Rockville, Md.: V. splendidus ATCC $33125^{\mathrm{T}}$ (type strain), V. natriegens ATCC $14048^{\mathrm{T}}, V$. pelagius biovar I ATCC $25916^{\mathrm{T}}, V$. pelagius biovar II ATCC $33504, V$. anguillarum ATCC $19264^{\mathrm{T}}, V$. harveyi ATCC $14126^{\mathrm{T}}$, and $V$. nereis ATCC $25917^{\mathrm{T}}$. The following strains were supplied by R.R.C. (equivalent ATCC or National Collection of Type Cultures [NCTC; London, United King- 
dom] designations are also given): $V$. alginolyticus 4228 (= ATCC $\left.17749^{\mathrm{T}}\right)$, 186, 11-10, 11-20, and 11-36; V. parahaemolyticus 196 (= ATCC $\left.17802^{\mathrm{T}}\right), 192$, and $191 ;$ V. vulnificus $4435\left(=\right.$ ATCC $\left.27567^{\mathrm{T}}\right), 425$, and $181 ; V$. cholerae 123 (= ATCC $\left.14035^{\mathrm{T}}\right) ; V$. fluvialis 11327 (= NCTC $\left.11327^{\mathrm{T}}\right) ; V$. furnissii 2386 (= NCTC 11328); V. metschnikovii 7708 (= ATCC 7708); $V$. damsela 4440; $V$. hollisae 4047; $V$. splendidus biovar II 4236 (= ATCC 25914); and Aeromonas hydrophila 4160.

Biochemical and physiological tests. Unless otherwise stated, all media were amended with $1 \%$ (wt/vol) $\mathrm{NaCl}$, inoculated with 1 or 2 drops from a Pasteur pipette of an overnight $T_{1} N_{1}$ broth culture, and incubated at $25^{\circ} \mathrm{C}$. All media were purchased from Difco Laboratories, Detroit, Mich., unless otherwise noted.

Strains were tested for production of amylase (33), arginine dihydrolase (28), lysine and ornithine decarboxylases (28), chitinase (33), oxidase (22), and acid from L-arabinose, $\mathrm{D}$-cellobiose, salicin, and sucrose in $\mathrm{O} / \mathrm{F}$ basal medium (33). Methyl red and Voges-Proskauer reactions were determined in methyl red Voges-Proskauer broth after 7 days. Reactions in triple-sugar iron (TSI) agar (Oxoid) were read after 18 to $24 \mathrm{~h}$ at $35^{\circ} \mathrm{C}$ and recorded as alkaline or acid. The presence of oxidative or fermentative metabolism was determined by using $\mathrm{O} / \mathrm{F}$ basal medium containing $1 \%$ (wt/vol) glucose.

A requirement for $\mathrm{NaCl}$ was determined visually as absence of growth after $48 \mathrm{~h}$ in $1 \%$ tryptone broth without added $\mathrm{NaCl}$. Growth in the presence of $\mathrm{NaCl}$ was tested in $1 \%$ tryptone broth supplemented with the appropriate concentration of $\mathrm{NaCl}$ (34). Growth at $40^{\circ} \mathrm{C}$ was determined visually after $48 \mathrm{~h}$ in $\mathrm{T}_{1} \mathrm{~N}_{1}$ broth.

Hydrolysis of $o$-nitrophenyl- $\beta$-D-galactopyranoside (22) was tested by using a suspension of cells from a 48-h NA plate supplemented with $1 \%$ (wt/vol) lactose (33). Sensitivity to $\mathrm{O} / 129$ (2,4-diamino-6,7-diisopropylpteridine) was determined by spot inoculation of NA containing 10,50 , and 150 $\mu \mathrm{g} / \mathrm{ml}$ (33). Production of urease was determined by spot inoculation of urea agar plates incubated for 20 to $24 \mathrm{~h} \mathrm{(28)}$.

Sole carbon and energy source. The ability to utilize a variety of compounds as sole carbon and energy sources was tested by adding the following compounds to a basal mineral salts medium (33) at a concentration of $0.1 \%(\mathrm{wt} / \mathrm{vol}$; $\mathrm{vol} / \mathrm{vol}$ for liquids). All strains were tested for utilization of 4aminobutyrate, L-arabinose, butyrate, D-cellobiose, ethanol, galacturonate, glucuronate, L-leucine, propanol, putrescine, and sucrose. Supplemental tests were conducted on 43 isolates for utilization of L-rhamnose, D-galactose, 5-aminovalerate, L-arginine, glycine, hippurate, L-ornithine, mannose, glutarate, glycerate, gluconate, $\alpha$-ketoglutarate, valerate, and L-citrulline. Sole carbon source plates were spot inoculated with an A400 multipoint inoculator (Denley, Sussex, England). The inoculum was prepared by diluting 1 or 2 drops of a 3- to 5-h $T_{1} N_{1}$ broth culture from a Pasteur pipette into $3 \mathrm{ml}$ of fresh $\mathrm{T}_{1} \mathrm{~N}_{1}$ broth. The biochemical and nutritional tests chosen were selected as a means of distinguishing among Vibrio species specifically from estuarine environments and not from pelagic regions of the oceans (2).

Morphology. Gram stains were prepared from overnight NA cultures. Flagellar staining was performed by the method of Mayfield and Inniss (23) on air-dried smears from overnight $T_{1} N_{1}$ broth cultures stained for 30 to $60 \mathrm{~s}$.

Test errors. Sixteen isolates were inoculated in duplicate to estimate the average probability of test errors. Errors were scattered among the tests, and the average probability of error was calculated to be approximately $5 \%$.

Moles percent guanine-plus-cytosine determinations. Prep- aration of DNA samples was performed as described by Johnson (11), with the following modifications. The cells were suspended and lysed in Tris-saline buffer $(\mathrm{pH} \mathrm{8)}$, containing $0.05 \mathrm{M}$ Tris (Bethesda Research Laboratories, Inc., Rockville, Md.) and $0.2 \mathrm{M} \mathrm{NaCl}$; the Tris-saline buffer was supplemented with sodium EDTA $(0.02 \mathrm{M}$ final concentration) at the time of lysis, and the cell suspension was frozen at $-70^{\circ} \mathrm{C}$ until required for further preparation.

The DNA was precipitated and purified (11), and after $1 \mathrm{~h}$ of incubation in RNase, pronase (Sigma Chemical Co., St. Louis, Mo.) was added to a final concentration of $100 \mu \mathrm{g} / \mathrm{ml}$ and incubation was continued for $1 \mathrm{~h}$ at $35^{\circ} \mathrm{C}$. The DNA was examined for purity by determining the $A_{230}, A_{260}$, and $A_{280}$ in a model 2600 spectrophotometer (Gilford Instrument Laboratories, Inc., Oberlin, Ohio). The same instrument was used to melt the DNA at temperatures increasing by $1^{\circ}$ $\mathrm{C} / \mathrm{min}$ to determine the moles percent guanine plus cytosine by the method of Mandel et al. (21). $V$. cholerae ATCC 14035 (47 mol\% guanine plus cytosine) and $V$. parahaemolyticus ATCC 17802 (46 mol\% guanine plus cytosine) were used as standards for moles percent guanine-pluscytosine calculations.

DNA relatedness analysis. DNA-DNA hybridization was conducted with 14 of the isolates (see Table 4) by using the batch hydroxyapatite thermal elution procedure $(4,5)$. DNAs from the type strains of $V$. parahaemolyticus (ATCC 27969), $V$. alginolyticus (ATCC 17749), and V. natriegens (ATCC 14048) were nick translated with ${ }^{32} \mathrm{P}$ (NEK-004; Dupont, NEN Bioproducts, Boston, Mass.), and reacted with unlabeled DNA from representative Vibrio isolates at both the optimal reassociation temperature of $60^{\circ} \mathrm{C}$ and the stringent incubation temperature of $75^{\circ} \mathrm{C}$. Relatedness was expressed as the relative binding ratio (RBR) and as the divergence in the melting temperature (dTm or $\Delta T_{m}$ ) (see Table 4). RBR is the amount of double-stranded DNA formed between labeled and unlabeled DNAs from different strains divided by the amount of double-stranded DNA formed between labeled and unlabeled DNAs from the same strain. RBR was calculated as a percentage to enable determination of similarity between strains. RBRs of $<70 \%$ for reactions at $60^{\circ} \mathrm{C}$ and $<55 \%$ for reactions at $75^{\circ} \mathrm{C}$ were considered the cutoff values for DNA relatedness at the species level.

The dTm expressed in degrees Celsius, is the difference in melting temperature between the homologous and heterologous DNA duplexes. A dTm of $5^{\circ} \mathrm{C}$ was considered the cutoff value for DNA relatedness at the species level.

Control reactions in which labeled DNA was incubated without unlabeled DNA were included, and the label-only control values were subtracted from all reactions before the RBR was calculated.

DNA from $V$. parahaemolyticus ATCC 17802, V. alginolyticus ATCC 17749, and Neisseria meningitidis Norway H355 were used as control reactions for the DNA-DNA hybridizations (see Table 4).

Computer analysis. Computer analysis was performed by using programs available from the Microbial Systematics Section, National Institute of Dental Research, Bethesda, Md. Biochemical and physiological data were submitted to the program TAXON (31) for cluster analysis using simple matching $(S)$ and Jaccard $(S j)$ coefficients and unweighted average linkage.

\section{RESULTS}

A total of 240 strains ( 229 isolates and 11 reference strains) clustered into 22 groups when the $S$ coefficient and un- 

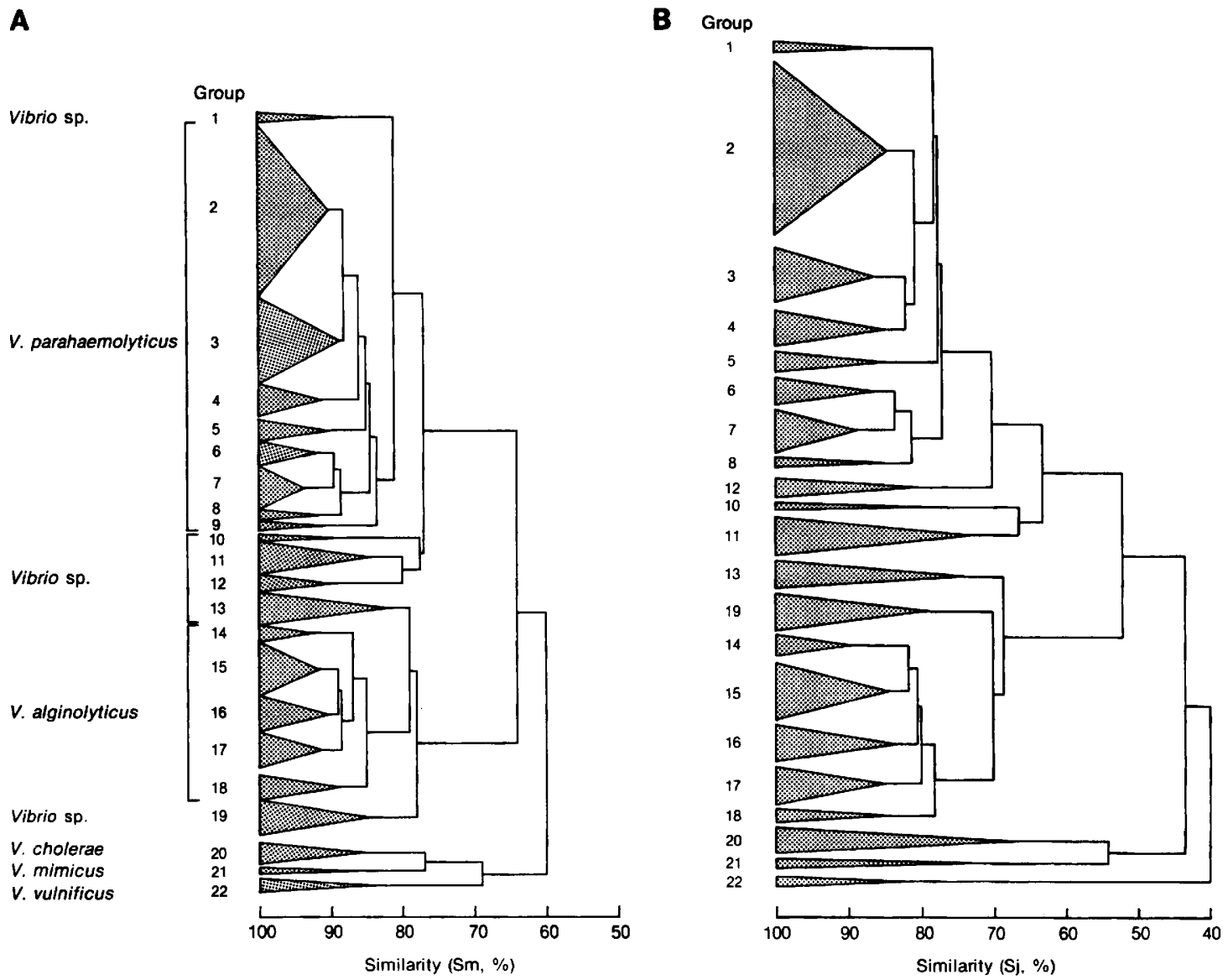

FIG. 1. Simplified dendrogram of the strains examined in this study by the $S$ (A) and $S j$ (B) coefficients, both with unweighted average linkage. The groups in panel B were numbered for consistency with those in panel A. Uniformly positive and negative features were omitted to increase the sensitivity of the analysis.

weighted average linkage were used (Fig. 1). Analysis using the $S j$ coefficient produced similar clusters. The two largest groups were identified as $V$. parahaemolyticus and $V$. alginolyticus. Three other groups also found as results of the analysis were identified as $V$. cholerae, $V$. mimicus, and $V$. vulnificus (Fig. 1).

Groups 1, 10-13, and 19 bordered on and were biochemically similar to $V$. parahaemolyticus and $V$. alginolyticus. Forty-three isolates within these groups and 22 reference strains were analyzed by using additional sole carbon source utilization tests and growth at $40^{\circ} \mathrm{C}$ to clarify relationships with $V$. parahaemolyticus and $V$. alginolyticus. Results of the second analysis are presented in the dendrogram shown in Fig. 2. In general, the groupings were not altered. A new group (group 23) was composed of strains H6922 and N186 (Fig. 2).

$V$. harveyi, $V$. furnissii, $V$. natriegens, $V$. nereis, $V$. anguillarum, $V$. fluvialis, $V$. metschnikovii, $V$. hollisae, $V$. damsela, V. splendidus, $V$. pelagius, and $A$. hydrophila did not cluster with any isolates in either analysis.

The DNA base composition of strain N219 was $44 \pm 1$ mol\% guanine plus cytosine. Group 1 was the only group in which all strains were capable of utilizing galacturonate and aminobutyrate (Table 1).

Groups 2 to 9 (Fig. 1) clustered at $S \geq 85 \%$ ( $S j \geq 70 \%$ ) with the type strain of $V$. parahaemolyticus 196 in group 3 . Strains within these clusters demonstrated characteristics of $V$. parahaemolyticus (Table 1). Distinguishing features of the larger subgroups of $V$. parahaemolyticus are shown in Table 2. $V$. parahaemolyticus reference strain 191 did not cluster with other strains when either the $S$ or $S j$ coefficient was used.

Groups 10 to 12 occupied a position between the $V$. parahaemolyticus and $V$. alginolyticus groups and clustered at $S \geq 78 \%$ ( $S j \geq 63 \%$ ) (Fig. 1). A consistent feature for all strains within these three groups was the inability to utilize ethanol or propanol (Tables 1 and 2).

Groups 10 and 11 were identified as $V$. parahaemolyticus. Group 10 contained two environmental isolates that clustered at $S \geq 88 \%(S j \geq 81 \%$ ) after the primary analysis (Fig. 1). After further testing and analysis, these strains joined $V$. parahaemolyticus $196^{\mathrm{T}}$ and 192 at $S \geq 82 \%$ ( $S j \geq 73 \%$ ) (Fig. 2). Group 11 included two environmental and seven clinical isolates that clustered at $S \geq 84 \%$ ( $S j \geq 73 \%$ ) (Fig. 1). After further testing and analysis, these strains joined $V$. parahaemolyticus $196^{\mathrm{T}}$ and 192 at $S \geq 82 \%$ ( $S j \geq 73 \%$ ) (Fig. 2).

Group 12 contained two environmental and three clinical isolates that clustered at $S \geq 90 \%(S j \geq 81 \%)$ and joined $V$. parahaemolyticus at $S \geq 77 \%$ ( $S j \geq 70 \%$ ) (Fig. 1). After further analysis, these strains clustered at $S \geq 86 \%(S j \geq$ $75 \%$ ) and joined $V$. parahaemolyticus 196 and 192 at $S \geq$ $80 \%(S j \geq 69 \%$ ) (Fig. 2). The DNA base composition of strain $\mathrm{H} 4309$ was $45 \pm 1 \mathrm{~mol} \%$ guanine plus cytosine.

Group 13 consisted of nine environmental isolates that clustered at $S \geq 82 \%$ ( $S j \geq 73 \%$ ) and joined $V$. alginolyticus groups at $S \geq 79 \%$ ( $S j \geq 68 \%$ ) (Fig. 1). Some features shared 


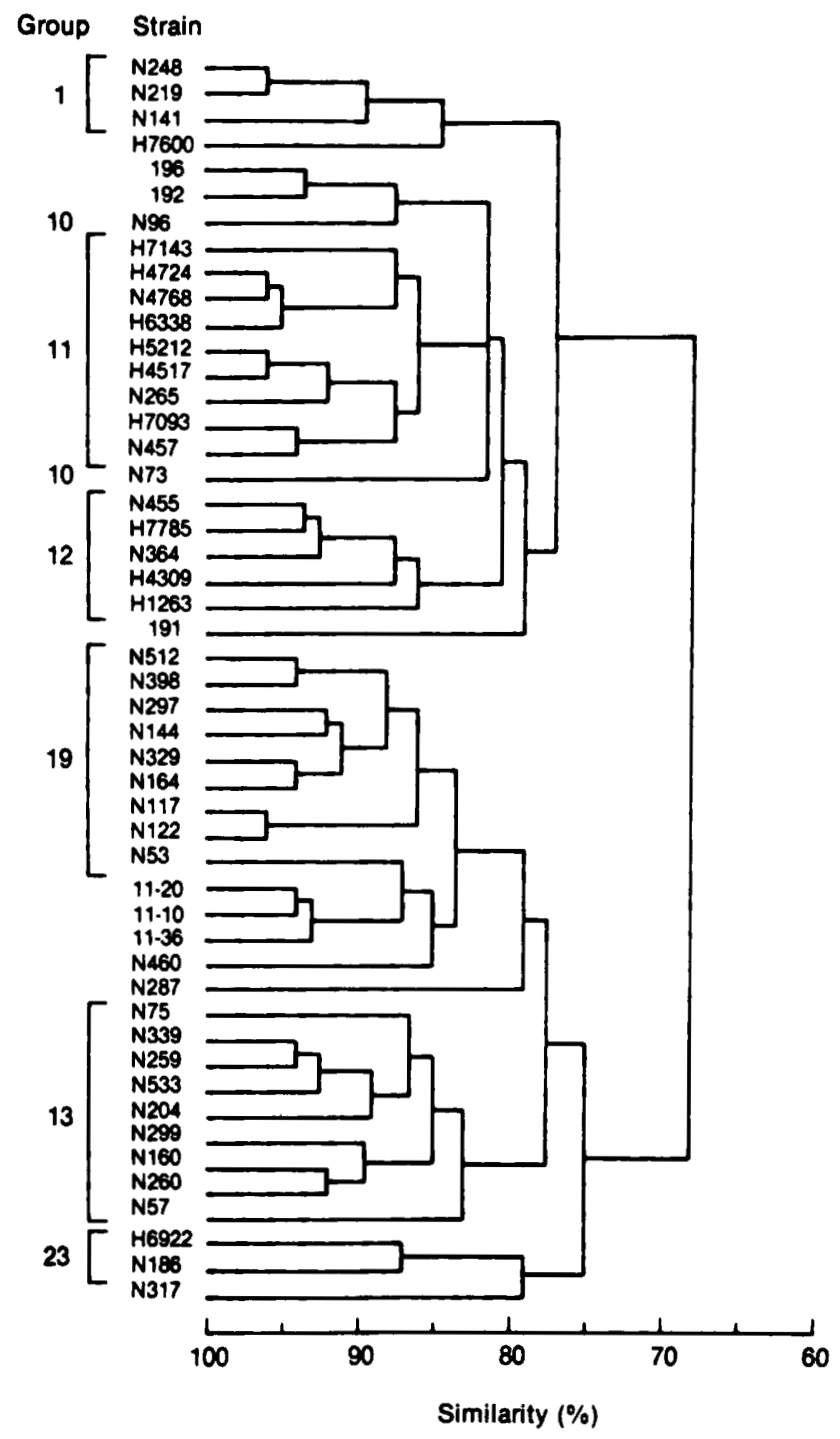

FIG. 2. Dendrogram resulting from taxonomic analysis of strains subjected to further testing with the $S$ coefficient and unweighted average linkage. The data included both the original and supplemental results. Uniformly positive and negative features were omitted to increase the sensitivity of the analysis. The groups are numbered for consistency with those in Fig. 1. H, Human clinical isolates; N, environmental isolates.

by this group with $V$. alginolyticus were the ability to produce acid from sucrose, production of acetoin, growth in the presence of $10 \% \mathrm{NaCl}$, growth at $40^{\circ} \mathrm{C}$, and inability to produce acid from arabinose (Table 1). All strains were gram-negative rods that produced polar flagella in $T_{1} N_{1}$ broth. The DNA base composition of two strains, N339 and N57, was $43 \pm 1 \mathrm{~mol} \%$ guanine plus cytosine. An interesting difference between strains in group 13 and $V$, alginolyticus was the TSI reaction (Table 1).

Groups 14 to 18 contained 48 environmental, 1 clinical, and $5 \mathrm{~V}$. alginolyticus reference strains that clustered at $S \geq$ $85 \%(S j \geq 77 \%$ ) (Fig. 1). Distinguishing features of the larger subgroups of $V$. alginolyticus are shown in Table 3.

Group 19 contained one clinical and nine environmental isolates that clustered at $S \geq 84 \%(S j \geq 79 \%)$ and joined the $V$. alginolyticus strains at $S \geq 78 \%(S j \geq 70 \%$ ) (Fig. 1). After further analysis, the nine environmental strains clustered at
$S \geq 86 \%(S j \geq 75 \%)$ and joined the $V$. alginolyticus reference strains at $S \geq 83 \%$ ( $S j \geq 72 \%$ ) (Fig. 2), while the clinical strain (H6922) separated into a new group (group 23). The DNA base composition of two strains, N122 and N104, was $44 \pm 1$ mol\% guanine plus cytosine. Although these traits initially identified this group as $V$. alginolyticus, the DNA relatedness data (Table 4) confirmed that group 19 is a species separate from $V$. alginolyticus.

Group 20 was identified as $V$. cholerae and contained one environmental isolate (from a milkfish specimen), four clinical isolates, and the $V$. cholerae type strain. These strains clustered at $S \geq 85 \%(S j \geq 68 \%)$ and joined the $V$. alginolyticus and V. parahaemolyticus strains at $S \geq 60 \%(S j \geq 44 \%)$ (Fig. 1). Distinctive features of this group are provided in Table 1.

Group 21 contained two clinical isolates that clustered at $S$ $\geq 86 \%$ ( $S j \geq 68 \%$ ) (Fig. 1) and was identified as $V$. mimicus. The identification of these isolates was based on the ability to grow in tryptone broth without supplemental $\mathrm{NaCl}$ and the utilization of glucuronate (Table 1).

Group 22 was composed of one environmental isolate (from a barracuda specimen) and three $V$. vulnificus reference strains that clustered at $S \geq 84 \%$ ( $S j \geq 69 \%$ ) (Fig. 1). These strains required $\mathrm{NaCl}$ for growth in tryptone broth but did not grow in $8 \% \mathrm{NaCl}$ (Table 1 ).

The second analysis created a new group, 23 , that clustered at $S \geq 87 \%(S j \geq 81 \%)$ and included one environmental isolate (from a spinefoot specimen) and one clinical isolate (Fig. 2). This was the only group in which strains produced acid from both L-arabinose and sucrose (Table 1). Both strains required added $\mathrm{NaCl}$ for growth in tryptone broth but did not grow in $10 \% \mathrm{NaCl}$ and produced amylase, lysine, and ornithine decarboxylases; and acid slant-acid butt reactions in TSI. They differed from $V$. parahaemolyticus in the utilization of sucrose and galactose and differed from $V$. alginolyticus in the utilization of L-arabinose, ethanol, and propanol (Table 1).

DNA relatedness analysis was conducted with 14 isolates belonging to groups $1,2,9$ to $14,18,19$, and 23 . The isolates were selected to represent the unidentified groups (groups 1, 12,13 , and 23), groups that bordered on these unidentified groups in either of the previous two analyses (groups 10,11, and 19), $V$. parahaemolyticus (groups 2 to 9), and $V$. alginolyticus (groups 14 to 18), together with one of the nongroupable strains (N287). It was possible to confirm the identification of groups $1,2,9$ to 12 , and 23 as $V$. parahaemolyticus and groups 13,14 , and 18 as $V$. alginolyticus, but group 19 remained unidentified and could be described only as a Vibrio species.

Except for groups 10 and 23, all isolates belonging to $V$. parahaemolyticus (groups $1,2,9,11$, and 12) were 78 to $93 \%$ related to the type strain of $V$. parahaemolyticus at both 60 and $75^{\circ} \mathrm{C}$, with dTms of -0.2 to $1.1^{\circ} \mathrm{C}$. Groups 10 and 23 were 70 and $72 \%$ related to $V$. parahaemolyticus, respectively. Although these values are very close to the cutoff for DNA relatedness at $60^{\circ} \mathrm{C}(<70 \%)$, identification of group 10 as $V$. parahaemolyticus was based on its $\operatorname{dTm}\left(0.4^{\circ} \mathrm{C}\right)$ and relatedness at $75^{\circ} \mathrm{C}(72 \%)$ (Table 4). Group 23 (strain H6922) was $72 \%$ related to $V$. parahaemolyticus at $60^{\circ} \mathrm{C}$, with a dTm of $0.2^{\circ} \mathrm{C}$ and relatedness of $67 \%$ at $75^{\circ} \mathrm{C}$.

Groups $1,2,9$ to 12 , and 23 were 23 to $53 \%$ related to the type strain of $V$. alginolyticus (ATCC 17749) at $60^{\circ} \mathrm{C}$, with dTms of 10.1 and $8.8^{\circ} \mathrm{C}$ for groups 1 and 2 , respectively. Groups 1 and 2 were 26 and $23 \%$ related to $V$. alginolyticus at $75^{\circ} \mathrm{C}$, respectively (Table 4 ).

$V$. alginolyticus (groups 13,14 , and 18 ) were 85 to $96 \%$ 
TABLE 1. Feature frequencies for the major groups obtained in this analysis

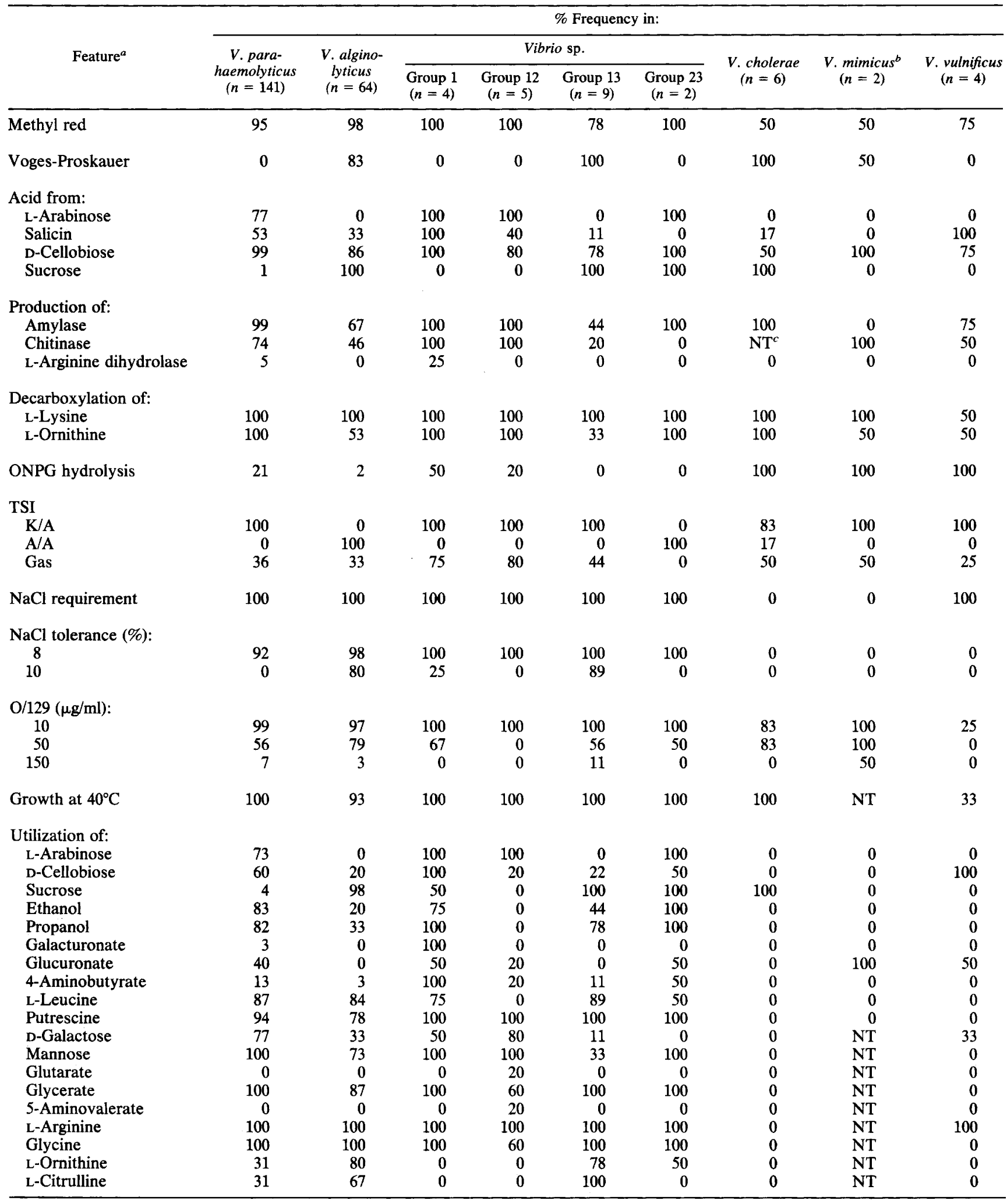

${ }^{a}$ All strains possessed fermentative metabolism, produced oxidase, and utilized $\alpha$-ketoglutarate and gluconate. None produced $\mathrm{H}_{2} \mathrm{~S}$ in TSI after $24 \mathrm{~h}$ or urease or utilized butyrate, L-rhamnose, valerate, or hippurate. ONPG, $o$-nitrophenyl- $\beta$-D-galactopyranoside. TSI reactions: K/A, alkaline slant-acid butt; A/A, acid slant-acid butt.

${ }^{b} \mathrm{~V}$. mimicus was not tested for utilization of $\alpha$-ketoglutarate, gluconate, L-rhamnose, valerate, or hippurate.

c NT, Not tested. 
TABLE 2. Features distinguishing the larger subgroups of $V$. parahaemolyticus

\begin{tabular}{lrrrc}
\hline \multirow{1}{*}{ Feature } & \multicolumn{5}{c}{ \% Frequency in: } \\
\cline { 2 - 5 } & $\begin{array}{l}\text { Group 2 } \\
(n=49)\end{array}$ & $\begin{array}{c}\text { Group 3 } \\
(n=24)\end{array}$ & $\begin{array}{c}\text { Group 7 } \\
(n=12)\end{array}$ & $\begin{array}{c}\text { Group 11 } \\
(n=9)\end{array}$ \\
\hline $\begin{array}{l}\text { Acid from: } \\
\text { L-Arabinose }\end{array}$ & 100 & 100 & 0 & 0 \\
Salicin & 59 & 38 & 0 & 82 \\
O/129 $(50 \mu \mathrm{g} / \mathrm{ml})$ & 95 & 13 & 36 & 30 \\
& & & & \\
Utilization of: & & & 0 & 0 \\
L-Arabinose & 98 & 92 & 100 & 0 \\
$\begin{array}{l}\text { Ethanol } \\
\text { Propanol }\end{array}$ & 98 & 100 & 100 & 0 \\
$\quad$ Glucuronate & 100 & 87 & 0 & 73 \\
\hline
\end{tabular}

related to the type strain of $V$. alginolyticus at $60^{\circ} \mathrm{C}$ and 83 to $93 \%$ related to the same type strain at $75^{\circ} \mathrm{C}$, and the $\mathrm{dTm}$ was 0.3 to $0.6^{\circ} \mathrm{C}$.

These groups were 37 to $50 \%$ related to the type strain of $V$. parahaemolyticus (ATCC 27969) at $60^{\circ} \mathrm{C}$. The dTm for group 18 was $11^{\circ} \mathrm{C}$. Group 18 was also $28 \%$ related to $V$. parahaemolyticus in reactions at $75^{\circ} \mathrm{C}$ (Table 4).

Group 19 (strain N329) was $68 \%$ related to $V$. alginolyticus (ATCC 17749 ) at $60^{\circ} \mathrm{C}$. Although this value is very close to the cutoff for DNA relatedness at $60^{\circ} \mathrm{C}(<70 \%)$, separation of group 19 from $V$. alginolyticus was based on the $\mathrm{dTm}$ $\left(5.2^{\circ} \mathrm{C}\right.$ for group 19 versus a cutoff value of $\left.\leq 5.0^{\circ} \mathrm{C}\right)$ and on relatedness at $75^{\circ} \mathrm{C}(53 \%$ for group 19 versus a cutoff value of $<55 \%$ ). This group was $48 \%$ related to $V$. parahaemolyticus ATCC 27969 at $60^{\circ} \mathrm{C}$, with a dTm of $9.1^{\circ} \mathrm{C}$ and relatedness of $22 \%$ at $75^{\circ} \mathrm{C}$ (Table 4 ).

Nongroupable strain N287 remained unidentified, as revealed by its low relatedness to $V$. parahaemolyticus $(41 \%$ at $60^{\circ} \mathrm{C} ; 18 \%$ at $\left.75^{\circ} \mathrm{C} ; 8.5^{\circ} \mathrm{C} \mathrm{dTm}\right)$ and $V$. alginolyticus $(66 \%$ at $60^{\circ} \mathrm{C} ; 47 \%$ at $75^{\circ} \mathrm{C} ; 4.7^{\circ} \mathrm{C} \mathrm{dTm}$ ) (Table 4 ).

All isolates in this analysis were only 15 to $28 \%$ related to the type strain of $V$. natriegens (ATCC 14048) (Table 4). These values were sufficient to exclude the possibility of identification for any of the isolates examined as $V$. natr-

TABLE 3. Features distinguishing the larger subgroups of $V$. alginolyticus

\begin{tabular}{|c|c|c|c|c|}
\hline \multirow[b]{2}{*}{ Feature } & \multicolumn{4}{|c|}{$\%$ Frequency in: } \\
\hline & $\begin{array}{l}\text { Group 15 } \\
(n=15)\end{array}$ & $\begin{array}{c}\text { Group 16 } \\
(n=10)\end{array}$ & $\begin{array}{l}\text { Group } 17 \\
(n=10)\end{array}$ & $\begin{array}{l}\text { Group 19 } \\
(n=10)\end{array}$ \\
\hline \multicolumn{5}{|l|}{ Acid from: } \\
\hline Salicin & 53 & 10 & 0 & 70 \\
\hline D-Cellobiose & 93 & 60 & 80 & 100 \\
\hline Gas in TSI & 0 & 90 & 30 & 50 \\
\hline $\begin{array}{l}\text { Decarboxylation of } \\
\text { L-ornithine }\end{array}$ & 73 & 30 & 40 & 90 \\
\hline $\begin{array}{l}\text { Susceptibility to } 0 / 129 \\
\quad(50 \mu \mathrm{g} / \mathrm{ml})\end{array}$ & 100 & 100 & 0 & 89 \\
\hline \multicolumn{5}{|l|}{ Utilization of: } \\
\hline D-Cellobiose & 7 & 0 & 10 & 80 \\
\hline Ethanol & 0 & 0 & 0 & 80 \\
\hline Propanol & 20 & 10 & 0 & 100 \\
\hline
\end{tabular}

iegens without determining the dTms or relatedness at $75^{\circ} \mathrm{C}$. $V$. natriegens was included in the study because previously (32) this species was observed to cluster very closely with $V$. parahaemolyticus.

\section{DISCUSSION}

The environmental and clinical isolates examined in this study clustered into 23 groups. Five species were identified by use of reference strains and/or characteristic features. It has been noted that the use of a range of tests to identify a particular species from one environmental habitat may not be applicable in another habitat (34). Nevertheless, results of this study indicate that taxonomic criteria for identification of $V$. parahaemolyticus, $V$. alginolyticus, $V$. cholerae, $V$. mimicus, and $V$. vulnificus are useful for identification of strains from seawater, seafood, and clinical specimens collected in Indonesia and included in this study.

The clusters of $V$. parahaemolyticus were mixtures of environmental and clinical isolates with no separation of the groupings ascribable to the source. Nutritional characteristics were in general agreement with those for $V$. parahaemolyticus (2). Results in some cases, e.g., fermentation of $\mathrm{L}$-arabinose and salicin, production of chitinase, and sensitivity to vibriostat $\mathrm{O} / 129(50 \mu \mathrm{g} / \mathrm{ml})$, were useful in distinguishing biotypes of $V$. parahaemolyticus but, in general, did not separate clinical and environmental isolates.

Identification of $V$. alginolyticus isolated from tropical waters and seafood was achieved by using standard tests (32, $33)$. The $V$. alginolyticus strains examined in this study were environmental isolates, except for a single clinical isolate. Interestingly, $V$. alginolyticus is rarely isolated from fecal specimens $(13,25)$.

Two diagnostic features of $V$. alginolyticus (groups 14 to 18 ), growth in $10 \% \mathrm{NaCl}$ and acetoin production, were positive for only about $80 \%$ of the strains (Table 1 ). The strains that contributed most of the negative results for these features were in group 18. Acetoin production has been reported to be relatively low and transient for some Vibrio strains (2) and is influenced by incubation time and temperature (33). Other studies have reported negative acetoin reactions (15). Inspection of specimens and dates of isolation for strains in group 18 revealed no consistent pattern to explain the negative results for growth in $10 \% \mathrm{NaCl}$. Larsen et al. (15) found that only $86 \%$ of human $V$. alginolyticus strains could grow in $10 \% \mathrm{NaCl}$, and others have also isolated strains negative for this characteristic $(17,27)$.

Two clinical isolates were identified as $V$. mimicus on the basis of their feature frequencies $(6,7)$. However, these strains produced acid from cellobiose (Table 1). Isolates from tropical areas in other studies were predominantly from clinical specimens, rarely from environmental sources $(6,7)$. However, many strains have been isolated from water or shellfish specimens in temperate climates. The possibility that a reservoir of $V$. mimicus exists in tropical environments requires further investigation.

Clinical and environmental strains of $V$. vulnificus have been isolated from many temperate areas $(13,24)$ and have been shown to be indistinguishable phenotypically (29). It should be pointed out that $V$. vulnificus has been isolated from fish in Senegalese coastal waters (26). In this study, $V$. vulnificus was observed to be distinct from other Vibrio species on the basis of taxonomic criteria (2).

The taxonomic traits of any group of organisms should be applicable to isolates from the environment. In this study, the taxonomic criteria used to describe Vibrio sp. were 
TABLE 4. DNA relatedness among representative Vibrio isolates and reference strains (V. parahaemolyticus, $V$. alginolyticus, and $V$. natriegens)

\begin{tabular}{|c|c|c|c|c|c|c|c|c|c|c|}
\hline \multirow{3}{*}{ Strain $^{b}$} & \multicolumn{2}{|c|}{ Source of unlabeled DNA } & \multicolumn{7}{|c|}{ Data for labeled DNA from ${ }^{a}$ : } & \multirow{3}{*}{$\begin{array}{l}\text { Confirmed } \\
\text { identification }\end{array}$} \\
\hline & \multirow{2}{*}{ Group } & \multirow{2}{*}{$\begin{array}{l}\text { Preliminary } \\
\text { identification }\end{array}$} & \multicolumn{3}{|c|}{$\begin{array}{c}V . \text { parahaemolyticus } \\
\text { ATCC } 27969\end{array}$} & \multicolumn{3}{|c|}{$\begin{array}{l}V . \text { alginolyticus } \\
\text { ATCC } 17749\end{array}$} & \multirow{2}{*}{$\begin{array}{c}V . \text { natriegens } \\
\text { ATCC } 14048 \\
\operatorname{RBR}\left(60^{\circ} \mathrm{C}\right)\end{array}$} & \\
\hline & & & $\begin{array}{c}\text { RBR } \\
\left(60^{\circ} \mathrm{C}\right)\end{array}$ & $\begin{array}{l}\mathrm{dTm} \\
\left({ }^{\circ} \mathrm{C}\right)\end{array}$ & $\begin{array}{c}\text { RBR } \\
\left(75^{\circ} \mathrm{C}\right)\end{array}$ & $\begin{array}{c}\text { RBR } \\
\left(60^{\circ} \mathrm{C}\right)\end{array}$ & $\begin{array}{l}\mathrm{dTm} \\
\left({ }^{\circ} \mathrm{C}\right)\end{array}$ & $\begin{array}{c}\text { RBR } \\
\left(75^{\circ} \mathrm{C}\right)\end{array}$ & & \\
\hline $\mathbf{N} 248$ & 1 & Vibrio $\mathrm{sp}$ & 93 & 1.1 & 89 & 53 & 10.1 & 26 & 15 & V. parahaemolyticus \\
\hline H7417 & 2 & V. parahaemolyticus & 80 & -0.2 & 78 & 44 & 8.8 & 23 & & V. parahaemolyticus \\
\hline H5247 & 9 & V. parahaemolyticus & 89 & 0.7 & 95 & 36 & & & 28 & V. parahaemolyticus \\
\hline N73 & 10 & $V$. parahaemolyticus & 70 & 0.4 & 72 & 23 & & & 18 & V. parahaemolyticus \\
\hline H4517 & 11 & $V$. parahaemolyticus & 86 & 0.7 & 96 & 34 & & & 23 & V. parahaemolyticus \\
\hline $\mathrm{N} 265$ & 11 & V. parahaemolyticus & 89 & 0.3 & 82 & 33 & & & 19 & V. parahaemolyticus \\
\hline H4309 & 12 & Vibrio sp. & 89 & 0.3 & 90 & 25 & & & 19 & V. parahaemolyticus \\
\hline N364 & 12 & Vibrio sp. & 84 & -0.1 & 78 & 27 & & & 18 & V. parahaemolyticus \\
\hline H6922 & 23 & Vibrio sp. & 72 & 0.2 & 67 & 32 & & & 23 & V. parahaemolyticus \\
\hline N533 & 13 & Vibrio sp. & 37 & & & 93 & 0.4 & 89 & 25 & V. alginolyticus \\
\hline $\mathrm{H} 7180$ & 14 & V. alginolyticus & 38 & & & 85 & 0.3 & 83 & 23 & V. alginolyticus \\
\hline N72 & 18 & V. alginolyticus & 50 & 11.0 & 28 & 96 & 0.6 & 93 & 23 & \\
\hline N329 & 19 & V. alginolyticus & 48 & 9.1 & 22 & 68 & 5.2 & 53 & 15 & Vibrio sp. \\
\hline N287 & Nongroupable & & 41 & 8.5 & 18 & 66 & 4.7 & 47 & 18 & Vibrio sp. \\
\hline $11-36 \mathrm{VA}$ & Reference & V. alginolyticus & 38 & & & 91 & 0.4 & 87 & 22 & \\
\hline ATCC 17749 & Reference & $V$. alginolyticus & 42 & 9.3 & 23 & 100 & 0.0 & 100 & & \\
\hline ATCC 17802 & Reference & V. parahaemolyticus & 87 & 0.6 & 88 & & & & & \\
\hline
\end{tabular}

${ }^{a}$ Blank space indicates not done. The results presented are averages of two separate analyses; the deviations were within acceptable limits relative to the cutoff values.

${ }^{b} \mathrm{~N}$, Environmental isolate; $\mathrm{H}$, human clinical isolate.

found to be useful in identifying environmental and clinical strains. Biotypes of $V$. parahaemolyticus and $V$. alginolyticus in this study could not be correlated with sources. The variability of selected taxonomic features in the unidentified groups emphasizes the need to use DNA hybridization for resolving their species designations.

DNA relatedness analysis proved useful in identifying the representative isolates of groups 1,12 , and 23 as $V$. parahaemolyticus and those of group 13 as $V$. alginolyticus. It also confirmed identification of groups 2 and 9 to 11,14 and 18 , and 19 as $V$. parahaemolyticus, $V$. alginolyticus, and Vibrio sp., respectively.

Another interesting finding was that group 19 appeared to be most similar to $V$. alginolyticus on the basis of numerical taxonomic and sole carbon source utilization data. The isolate (N32a) selected to represent this group was similar to $V$. alginolyticus by DNA relatedness analysis; e.g., it was $68 \%$ related to the type strain of $V$. alginolyticus (ATCC 17749 ) in reactions at $60^{\circ} \mathrm{C}$. However, the $\mathrm{dTm}$ was very high $\left(5.2^{\circ} \mathrm{C}\right)$ and relatedness dropped to $53 \%$ in the reaction at $75^{\circ} \mathrm{C}$. Thus, this group is concluded to be a separate species, distinct from $V$. alginolyticus. Group 19 and strain N287, which did not cluster with any of the groups, remained unidentified. Further research with additional reference strains should resolve the species designation of these organisms within the genus Vibrio.

The recently described species $V$. aestuarianus, $V$. orientalis, $V$. diazotrophicus, and $V$. tubiashii differ from the isolates examined in this study by at least two of the following features: arginine dihydrolase; lysine and ornithine decarboxylases; acid from L-arabinose, sucrose, or salicin; and growth at $40^{\circ} \mathrm{C}(8,9,30,35)$.

The possible existence of new Vibrio spp. previously unrecognized, as seen in this study, suggests that further studies of vibrios in tropical climates will prove both informative and useful.

\section{ACKNOWLEDGMENTS}

This study was conducted in part by S.W.J. at Naval Medical Research Unit-2, Jakarta Detachment, Jakarta, Indonesia, and the Naval Medical Research Institute, Bethesda, Md. This work was supported in part by National Science Foundation systematics grant BSR8401397, World Health Organization grant C6-181-70, and Naval Medical Research and Development Command work unit MF51.524.009.0040B.

\section{LITERATURE CITED}

1. Baumann, P., L. Baumann, and M. Mandel. 1971. Taxonomy of marine bacteria: the genus Beneckea. J. Bacteriol. 107:268-294.

2. Baumann, P., and R. H. W. Schubert. 1984. Vibrionaceae, p. 516-538. In N. R. Krieg (ed.), Bergey's manual of systematic bacteriology, vol. 1. The Williams \& Wilkins Co., Baltimore.

3. Brayton, P. R., R. B. Bode, R. R. Colwell, M. T. MacDonell, H. L. Hall, D. J. Grimes, P. A. West, and T. N. Bryant. 1986. Vibrio cincinnatiensis sp. nov., a new human pathogen. J. Clin. Microbiol. 23:104-108.

4. Brenner, D. J., G. R. Fanning, A. V. Rake, and K. E. Johnson. 1969. Batch procedure for thermal elution of DNA from hydroxyapatite. Anal. Biochem. 28:447-459.

5. Brenner, D. J., A. C. McWhorter, J. K. Leete-Knutson, and A. G. Steigerwalt. 1982. Escherichia vulneris: a new species of Enterobacteriaceae associated with human wounds. J. Clin. Microbiol. 15:1133-1190.

6. Davis, B. R., G. R. Fanning, J. M. Madden, A. G. Steigerwalt, H. B. Bradford, Jr., H. L. Smith, Jr., and D. J. Brenner. 1981. Characterization of atypical Vibrio cholerae strains and description of a new pathogenic species, Vibrio mimicus. J. Clin. Microbiol. 14:631-639.

7. Desmarchelier, P. M., and J. L. Reichelt. 1984. A phenotypic and genetic study of sucrose nonfermenting strains of Vibrio mimicus and Vibrio cholerae. Curr. Microbiol. 10:41-48.

8. Guerinot, M. L., P. A. West, J. V. Lee, and R. R. Colwell. 1982. Vibrio diazotrophicus sp. nov., a marine nitrogen-fixing bacterium. Int. J. Syst. Bacteriol. 32:350-357.

9. Hada, H. S., P. A. West, J. V. Lee, J. Stemmler, and R. R. Colwell. 1984. Vibrio tubiashii sp. nov., a pathogen of bivalve 
mollusks. Int. J. Syst. Bacteriol. 34:1-4.

10. Janda, J. M., C. Powers, R. G. Bryant, and S. L. Abbott. 1988. Current perspectives on the epidemiology and pathogenesis of clinically significant Vibrio spp. Clin. Microbiol. Rev. 1:245267.

11. Johnson, J. L. 1981. Genetic characterization, p. 450-472. In P. Gerhardt, R. G. E. Murray, R. N. Costilow, E. W. Nester, W. A. Wood, N. R. Krieg, and G. B. Phillips (ed.), Manual of methods for general bacteriology. American Society for Microbiology, Washington, D.C.

12. Joseph, S. W. 1974. Observations on Vibrio parahaemolyticus in Indonesia, p. 35-40. In T. Fujino, G. Sakaguchi, R. Sakazaki, and Y. Takeda (ed.), International Symposium on Vibrio parahaemolyticus. Saikon Publishing Co., Tokyo.

13. Joseph, S. W., R. R. Colwell, and J. B. Kaper. 1983. Vibrio parahaemolyticus and related halophilic vibrios. Crit. Rev. Microbiol. 10:77-124.

14. Kaper, F. B., H. Lockman, E. F. Remmers, K. Kristensen, and R. R. Colwell. 1983. Numerical taxonomy of vibrios isolated from estuarine environments. Int. J. Syst. Bacteriol. 33:229255.

15. Larsen, J. L., A. F. Farid, and I. Dalsgaard. 1981. A comprehensive study of environmental and human pathogenic Vibrio alginolyticus strains. Zentralbl. Bakteriol. Mikrobiol. Hyg. 1 Abt. Orig. A 251:213-222.

16. Lee, J. V., T. J. Donovan, and A. L. Furniss. 1978. Characterization, taxonomy, and emended description of Vibrio metschnikovii. Int. J. Syst. Bacteriol. 28:99-111.

17. Lee, J. V., M. S. Hendrie, and J. M. Shewan. 1979. Identification of Aeromonas, Vibrio, and related organisms, p. 151-166. In F. A. Skinner and D. W. Lovelock (ed.), Identification methods for microbiologists, 2nd ed. Academic Press, London.

18. Lee, J. V., P. Shread, and A. L. Furniss. 1981. Taxonomy and description of Vibrio fluvialis sp. nov. (synonym group $\mathrm{F}$ vibrios, group EF6). J. Appl. Bacteriol. 50:73-94.

19. Love, M. D. Teebken-Fisher, J. H. Hose, J. J. Farmer III, F. W. Hickman, and G. R. Fanning. 1981. Vibrio damsela, a marine bacterium, causes skin ulcers on the damselfish Chromis punctipinnis. Science 214:1139-1140.

20. MacDonell, M. T., and R. R. Colwell. 1985. Phylogeny of the Vibrionaceae, and recommendation for two new genera, Listonella and Shewanella. Syst. Appl. Microbiol. 6:171-182.

21. Mandel, M., L. Iganbi, J. Bergendahl, M. L. Dodson, Jr., and E. Scheltgen. 1970. Correlation of melting temperature and cesium chloride buoyant density of bacterial deoxyribonucleic acid. J. Bacteriol. 101:333-338.

22. MacFaddin, J. F. 1980. Biochemical tests for identification of medical bacteria. The Williams \& Wilkins Co., Baltimore.

23. Mayfield, C. I., and W. E. Inniss. 1977. A rapid, simple method for staining bacterial flagella. Can. J. Microbiol. 23:1311-1313.

24. Oliver, J. D., R. A. Warner, and D. R. Cleland. 1982. Distribution and ecology of Vibrio vulnificus and other lactose-fermenting marine vibrios in coastal waters of the southeastern United States. Appl. Environ. Microbiol. 44:1404-1414.

25. Sakazaki, R., S. Iwanami, and H. Fukumi. 1963. Studies on the enteropathogenic, facultatively halophilic bacteria, Vibrio parahaemolyticus. I. Morphological, cultural and biochemical properties and its taxonomical position. Jpn. Med. Sci. Biol. 16: 161-188.

26. Schandevyl, P., E. Van Dyck, and P. Piot. 1984. Halophilic Vibrio species from seafish in Senegal. Appl. Environ. Microbiol. 48:236-238.

27. Schmidt, U., H. Chmel, and C. Cobbs. 1979. Vibrio alginolyticus infections in humans. J. Clin. Microbiol. 10:666-668.

28. Smibert, R. M., and N. R. Kreig. 1981. General characterization, p. 409-443. In P. Gerhardt, R. G. E. Murray, R. N. Costilow, E. W. Nester, W. A. Wood, N. R. Krieg, and G. B. Phillips (ed.), Manual of methods for general bacteriology. American Society for Microbiology, Washington, D.C.

29. Tison, D. L., and R. J. Seidler. 1981. Genetic relatedness of clinical and environmental isolates of lactose-positive Vibrio vulnificus. Curr. Microbiol. 6:181-184.

30. Tison, D. L., and R. J. Seidler. 1983. Vibrio aestuarianus: a new species from estuarine waters and shellfish. Int. J. Syst. Bacteriol. 33:699-702.

31. Walczak, C. A., and M. I. Krichevsky. 1980. Computer methods for describing groups from binary phenetic data: modification of numerical taxonomy programs to increase flexibility. Int. J. Syst. Bacteriol. 30:622-626.

32. West, P. A., P. R. Brayton, T. N. Bryant, and R. R. Colwell. 1986. Numerical taxonomy of Vibrios isolated from aquatic environments. Int. J. Syst. Bacteriol. 36:531-543.

33. West, P. A., and R. R. Colwell. 1984. Identification and classification of Vibrionaceae-an overview, p. 285-363. In R. R. Colwell (ed.), Vibrios in the environment. John Wiley \& Sons, Inc., New York.

34. West, P. A., J. V. Lee, and T. N. Bryant. 1983. A numerical taxonomic study of species of Vibrio isolated from the aquatic environment and birds in Kent, England. J. Appl. Bacteriol. 55:263-282.

35. Yang, Y., L. pen Yeh, Y. Cao, L. Baumann, P. Baumann, J. Sung-en Tang, and B. Beaman. 1983. Characterization of marine luminous bacteria isolated off the coast of China and description of Vibrio orientalis sp. nov. Curr. Microbiol. 8:95-100. 